\title{
Penentu Perilaku Keuangan Karyawan Muda Di Jakarta Dengan Literasi Keuangan Sebagai Variabel Mediasi
}

\author{
Nicholas Tanada dan Ign. Roni Setyawan \\ Program Studi Manajemen, Fakultas Ekonomi dan Bisnis \\ Universitas Tarumanagara, Jakarta \\ Email nicholas.tanada@yahoo.com
}

\begin{abstract}
The purpose of this study is to determine whether the financial behavior of young employees can be measured through financial literacy, where the level of financial literacy in this study is seen based on financial attitudes and financial socialization. Sample collection was carried out using the Google Form online questionnaire with a nonprobability sampling method of the type of purposive sampling with a total of 100 young employee respondents in Jakarta. Data processing is performed by the PLS-SEM method and calculations on the SmartPLS application 3.2.8. The results of this study indicate that financial attitudes and financial socialization, as well as financial literacy mediation variables have a significant positive effect on financial behavior. Meanwhile, financial attitudes have an insignificant indirect effect on financial behavior, through financial literacy.
\end{abstract}

Keywords: Financial Attitudes, Financial Socialization, Financial Literacy, Financial Behavior

Abstrak: Tujuan penelitian ini adalah untuk mengetahui apakah perilaku keuangan karyawan muda dapat diukur melalui literasi keuangan nya, dimana tingkat literasi keuangan dalam penelitian ini dilihat berdasarkan sikap keuangan dan sosialisasi keuangan seseorang. Pengumpulan sampel dilakukan dengan menggunakan kuesioner online Google Form dengan metode non-probability sampling berjenis purposive sampling dengan total 100 responden karyawan muda di Jakarta. Pengolahan data dilakukan dengan metode PLS-SEM dan kalkulasi pada aplikasi SmartPLS 3.2.8. Hasil penelitian ini menunjukan bahwa sikap keuangan dan sosialisasi keuangan, serta variabel mediasi literasi keuangan memiliki pengaruh positif signifikan terhadap peilaku keuangan. Sedangkan, sikap keuangan memiliki pengaruh tidak langsung yang tidak signifikan terhadap perilaku keuangan, melalui variabel mediasi literasi keuangan.

Kata kunci: Sikap Keuangan, Sosialisasi Keuangan, Literasi Keuangan, Perilaku Keuangan

\section{LATAR BELAKANG}

Setiap individu ingin sejahtera dan memiliki kebebasan finansial. Kebebasan finansial merupakan mimpi bagi setiap orang di dunia. Orang yang telah mencapai level kebebasan finansial tidak lagi takut akan krisis finansial yang bisa membuat seseorang jatuh miskin. Pengetahuan, sikap dan implementasi seseorang dalam mengelola keuangan pribadi dikenal dengan istilah literasi keuangan atau literasi finansial. Literasi keuangan erat kaitannya dengan manajemen keuangan dimana semakin tinggi tingkat literasi keuangan seseorang maka makin baik pula manajemen keuangan seseorang tersebut (Yushita, 2017). 
Menurut OJK (Otoritas Jasa Keuangan, 2016) literasi keuangan merupakan suatu rangkaian proses yang ditempuh seseorang berkaitan dengan kemampuan, kepedulian, serta pengambilan keputusan terkait keuangan secara pribadi. Survei Nasional Literasi dan Inklusi Keuangan (SNLIK) pada tahun 2016 menunjukkan indeks literasi keuangan sebesar 29,66\%. Angka ini dinilai meningkat dari hasil SNLIK pada 2013, yaitu indeks literasi keuangan 21,84\%. Melalui hasil survei ini dapat diketahui bahwa telah terjadi peningkatan akan pemahaman keuangan (well literate) dari 21,84\% menjadi 29,66\%.

Sosialisasi Keuangan. Sikap adalah kontributor penting bagi kesuksesan keuangan pribadi atau kegagalan. Meskipun demikian, beberapa penelitian telah dilakukan yang meneliti uang, sikap untuk memanajemen dan keuangan pribadi merupakan kunci perilaku keuangan baik secara terpisah atau bersamaan dengan pengetahuan atau perilaku. (Marsh, 2006). Sikap keuangan memainkan peran penting dalam menentukan perilaku keuangan seseorang (Davis dan Schumm, 1987; Shih dan Ke, 2014) dalam Mien dan Thao (2015).

Sosialisasi Keuangan. Ameliawati dan Setiyani (2018) menjelaskan bahwa pendidikan, peran pendidikan memberikan pengetahuan dan pemahaman ilmu keuangan sehingga dapat meningkatkan tingkat literasi keuangan yang dimiliki. Selain orang tua, teman-teman juga memengaruhi tingkat keuangan siswa, teman yang sering mendiskusikan tentang keuangan sampai seseorang menjadi lebih memahami tentang keuangan.

Gudmunson dan Danes (2011) membagi model sosialisasi keuangan keluarga (FFS) yang mencakup dua bagian, proses sosialisasi dan hasil sosialisasi. Proses sosialisasi keuangan didorong oleh interaksi dalam keluarga yang menyediakan pendidikan keuangan dan komunikasi norma-norma keuangan satu sama lain baik secara sengaja atau tidak sengaja.

Literasi Keuangan. Menurut Otoritas Jasa Keuangan (OJK) pada tahun 2014, literasi keuangan adalah keyakinan masyarakat, berdasarkan tingkat pengetahuan, dan keterampilan, mengenai produk serta lembaga keuangan yang dideskripsikan dalam parameter ukuran indeks. Literasi keuangan memiliki beberpa tingkatan dalam mengukur seberapa baik literasi keuangan seseorang. Terdapat 4 level literasi keuangan, yaitu Well Literate, Sufficient Literate, Less Literate, Not Literate. (Yushita, 2017)

Perilaku Keuangan. Behavior finance adalah suatu perilaku yang berkaitan dengan aplikasi keuangan. Menurut Ricciardi (2000) dalam (Arifin, Kevin dan Siswanto, 2017), behavioral finance adalah suatu displin ilmu yang di dalamnya melekat interaksi berbagai displin ilmu dan secara terus menerus berintegrasi sehingga pembahasannya tidak dilakukan isolasi. 3 aspek yang mempengaruhi financial behavior seseorang adalah psikologi, sosiologi, dan keuangan. Untuk dapat mempelajari perilaku keuangan harus memiliki pengertian mengenai aspek psikologi, sosiologi, dan keuangan.

\section{KAJIAN TEORI}

Theory of Financial Literacy. Model teoritis memasukkan komponen kunci perilaku individu dalam menggunakan uang dan lingkungan ekonomi secara implisit. Teori ini menganggap bahwa merumuskan dan melaksanakan tabungan dan rencana pengeluaran 
adalah hal yang penting bagi setiap individu, hal ini membutuhkan keahlian dalam berurusan dengan pasar keuangan, pengetahuan tentang daya beli, dan kapasitas untuk melakukan perhitungan ekonomi. (Lusardi dan Mitchell, 2013).

Nudge Theory. NudgeTheory mengatakan bahwa untuk dapat menentukan suatu pilihan yang tepat, berupa aturan maupun anjuran, harus didasarkan pada pemikiran mengenai dampak yang terjadi, dengan perpaduan bantuan insting atau disebut dengan variabel emosional teori ini berbanding terbalik system diruang lingkup pemerintahan yang sering mempergunakan asumsi bahwa seseorang selalu mengambil keputusan melalui proses berpikir secara rasional dan logika. (Kompasiana.com , 2017)

Social Learning Theory. Merupakan teori yang dikemukakan oleh Bandura, seseorang cenderung memilih dan mengubah perilakunya berdasarkan lingkungan dan pengaruh dari orang tua. Dalam penelitian ini, sosialisasi keuangan orang tua, pendidikan, teman sebaya, dan media akan mewakili interaksi dengan lingkungan serta dapat mengubah perilaku seseorang kearah yang lebih baik dalam mengelola keuangan. (Fluellen, 2013).

\section{METODOLOGI}

Penelitian ini menggunakan metode cross-sectional design yaitu proses pengumpulan data dari sampel suatu populasi yang hanya dilakukan sekali pada waktu tertentu saja, dikarenakan adanya keterbatasan pada penelitian.

Teknik pengambilan sample menggunakan metode non-probability sampling, sampel yang dikumpulkan seluruh individu memiliki kesempatan yang sama untuk terpilih menjadi sampel. Selanjutnya, teknik yang digunakan yakni purposive sampling dan masih merupakan bagian dari metode non-probability sampling.

Setiap variabel diukur menggunakan skala likert, di mana setiap variabel memiliki indikator tersendiri, dan akan diukur dengan skor berkisar 1-5

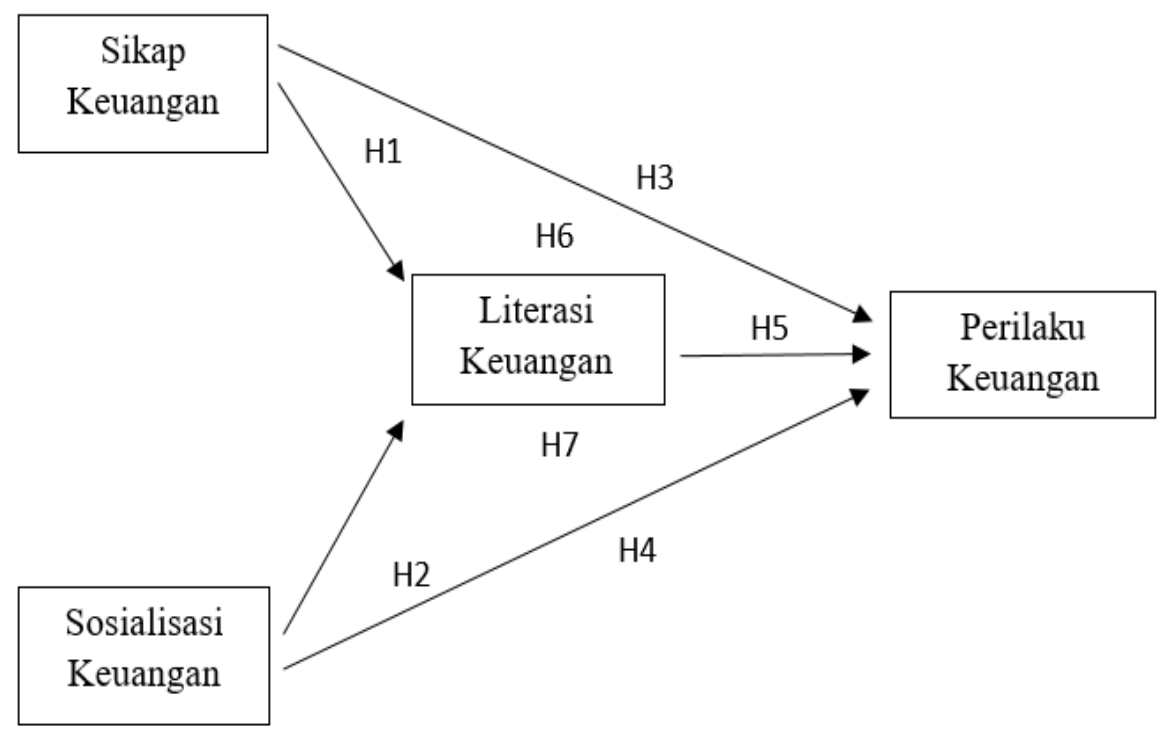




\section{Gambar 1. Model Struktural Penelitian}

H1: Terdapat pengaruh Sikap Keuangan terhadap Literasi Keuangan karyawan muda di Jakarta.

H2: Terdapat pengaruh Sosialisasi Keuangan terhadap Literasi Keuangan karyawan muda di Jakarta.

H3: Terdapat pengaruh Sikap Keuangan terhadap Perilaku Keuangan karyawan muda di Jakarta.

H4: Terdapat pengaruh Sosialisasi Keuangan terhadap Perilaku Keuangan karyawan muda di Jakarta.

H5: Terdapat pengaruh Literasi Keuangan terhadap Perilaku Keuangan karyawan muda di Jakarta.

H6: Terdapat pengaruh Sikap Keuangan terhadap Perilaku Keuangan karyawan muda di Jakarta melalui variabel mediasi Literasi Keuangan.

H7: Terdapat pengaruh Literasi Keuangan terhadap Perilaku Keuangan karyawan muda di Jakarta melalui variabel mediasi Literasi Keuangan.

Hasil Analisis Data

Uji Convergent Validity

Pada bagian ini, data yang berhasil dikumpulkan melalui platform online google form akan diuji berdasarkan model struktural penelitian ini dan dikalkulasi menggunakan software SmartPLS 3.2.8.

Tabel 1. Hasil Uji Validitas

\begin{tabular}{|c|c|}
\hline & Average Variance Extracted (AVE) \\
\hline Sikap Keuangan & $\mathbf{0 , 5 2 2}$ \\
\hline Sosialisasi Keuangan & $\mathbf{0 , 5 0 5}$ \\
\hline Literasi Keuangan & $\mathbf{0 , 6 3 8}$ \\
\hline Perilaku Keuangan & $\mathbf{0 , 5 1 3}$ \\
\hline
\end{tabular}

Nilai AVE lebih besar dari 0,50 (AVE> 0,50) seluruh variabel telah memenuhi kriteria. Sehingga dapat disimpulkan penelitian ini telah lolos dalam pengujian convergent validity.

Uji Discriminant Validity. Pengujian Discriminant validity memandang setiap pengukur (manifest variable) indikator yang berbeda tidak memiliki korelasi yang lebih tinggi dibanding indikator-indikator konstruk lain.

Tabel 2. Hasil Analisis Fornell-Larcker

\begin{tabular}{|l|r|r|r|r|}
\hline & $\begin{array}{c}\text { Financial } \\
\text { Behavior }\end{array}$ & $\begin{array}{c}\text { Financial } \\
\text { Socialization }\end{array}$ & $\begin{array}{l}\text { Financial } \\
\text { Attitude }\end{array}$ & $\begin{array}{l}\text { Financial } \\
\text { Literacy }\end{array}$ \\
\hline Financial Behavior & 0,716 & & & \\
\hline Financial Socialization & 0,698 & 0,711 & & \\
\hline Financial Attitude & 0,673 & 0,700 & 0,725 & \\
\hline Financial Literacy & 0,702 & 0,689 & 0,612 & 0,799 \\
\hline
\end{tabular}


Berdasarkan kalkulasi aplikasi SmartPLS, seluruh indikator telah memenuhi kriteria fornell-larcker, karena nilai AVE masing-masing konstruk lebih besar dari nilai korelasi antar konstruk. Sehingga seluruh variabel telah lolos pengujian convergent and construct validity maupun discriminant validity.

Path Coefficients. Tujuan dari dilakukannya analisis path coefficients yakni untuk menunjukkan keterkaitan antara satu variabel dengan variabel lainnya pada penelitian

Tabel 3. Hasil Bootsrapping

\begin{tabular}{|c|c|c|c|}
\hline \multirow{2}{*}{ Variabel } & \multicolumn{3}{|c|}{ Perilaku Keuangan } \\
\cline { 2 - 4 } & Path Coefficients & t-stat & p-values \\
\hline Sikap Keuangan & 0,272 & 2,502 & 0,013 \\
\hline Sosialisasi Keuangan & 0,264 & 2,723 & 0,007 \\
\hline Literasi Keuangan & 0,354 & 2,868 & 0,004 \\
\hline Mediating Effect 1 & 0,090 & 1,670 & 0,096 \\
\hline Mediating Effect 2 & 0,181 & 2,551 & 0,011 \\
\hline
\end{tabular}

Berdasarkan hasil bootstrapping, variabel sikap keuangan merupakan prediktor positif terhadap perilaku keuangan dengan nilai sebesar 0,272. Variabel sosialisasi keuangan juga merupakan prediktor positif terhadap perilaku keuangan dengan nilai sebesar 0,264. Variabel literasi keuangan merupakan prediktor positif terhadap perilaku keuangan dengan nilai 0,354 . Efek mediasi pertama menunjukan hubungan positif namun tidak signifikan sebesar 0,090. Efek mediasi kedua menunjukan pengaruh sebesar 0,181 dari variabel independen melalui variabel mediasi.

Tabel 4. Hasil Pengujian Hipotesis

\begin{tabular}{|c|l|c|}
\hline Kode & \multicolumn{1}{|c|}{ Hipotesis } & Hasil \\
\hline Ha1 & $\begin{array}{l}\text { Terdapat pengaruh positif Sikap Keuangan terhadap } \\
\text { Literasi Keuangan karyawan muda di Jakarta. }\end{array}$ & $\begin{array}{c}\text { Tidak } \\
\text { ditolak }\end{array}$ \\
\hline Ha2 & $\begin{array}{l}\text { Terdapat pengaruh positif Sosialisasi Keuangan terhadap } \\
\text { Literasi Keuangan karyawan muda di Jakarta. }\end{array}$ & $\begin{array}{c}\text { Tidak } \\
\text { ditolak }\end{array}$ \\
\hline Ha3 & $\begin{array}{l}\text { Terdapat pengaruh positif Sikap Keuangan terhadap } \\
\text { Perilaku Keuangan karyawan muda di Jakarta. }\end{array}$ & $\begin{array}{c}\text { Tidak } \\
\text { ditolak }\end{array}$ \\
\hline Ha4 & $\begin{array}{l}\text { Terdapat pengaruh positif Sosialisasi Keuangan terhadap } \\
\text { Perilaku Keuangan karyawan muda di Jakarta. }\end{array}$ & $\begin{array}{c}\text { Tidak } \\
\text { ditolak }\end{array}$ \\
\hline Ha5 & $\begin{array}{l}\text { Terdapat pengaruh positif Literasi Keuangan terhadap } \\
\text { Perilaku Keuangan karyawan muda di Jakarta. }\end{array}$ & $\begin{array}{c}\text { Tidak } \\
\text { ditolak }\end{array}$ \\
\hline Ha6 & $\begin{array}{l}\text { Terdapat pengaruh positif Sikap Keuangan terhadap } \\
\text { Perilaku Keuangan karyawan muda di Jakarta melalui } \\
\text { variabel mediasi Literasi Keuangan. }\end{array}$ & Ditolak \\
\hline Ha7 & $\begin{array}{l}\text { Terdapat pengaruh positif Sosialisasi Keuangan terhadap } \\
\text { Perilaku Keuangan karyawan muda di Jakarta melalui } \\
\text { variabel mediasi Literasi Keuangan. }\end{array}$ & $\begin{array}{c}\text { Tidak } \\
\text { ditolak }\end{array}$ \\
\hline
\end{tabular}




\section{DISKUSI}

Pengaruh Sikap Keuangan terhadap Literasi Keuangan. Hasil analisis data di aplikasi SmartPLS menunjukan bahwa $\mathrm{H} 1$ tidak ditolak (diterima), sehingga variabel sikap keuangan (financial attitude) memiliki pengaruh positif positif atas variabel literasi keuangan (financial literacy).Penelitian ini mendukung riset Ameliawati (2018) yang meneliti karakteristik kepribadian yang menyatakan bahwa sikap keuangan memiliki pengaruh yang signifikan terhadap literasi keuangan, disimpulkan bahwa ciri-ciri karakteristik personel seperti keuangan secara signifikan tidak mempengaruhi kearifan keuangan yang tidak terpikirkan.

Pengaruh Sosialisasi Keuangan terhadap Literasi Keuangan. Sosialisasi keuangan mempengaruhi literasi keuangan. Semakin banyak sosialisasi keuangan, maka semakin baik literasi keuangan karyawan muda. Sebaliknya, semakin sedikit sosialisasi keuangan maka tingkat literasi keuangan yang dimiliki juga akan semakin rendah. Sosialisasi keuangan dalam penelitian ini diperoleh melalui orang tua, pendidikan, teman, dan media.

Pengaruh Sikap Keuangan terhadap Perilaku Keuangan. Sikap keuangan merupakan kontributor penting dalam mencapai keberhasilan atau kegagalan aspek finansial. Sikap yang baik akan memengaruhi perilaku yang baik. Hasil penelitian ini sesuai dengan teori pembelajaran sosial yang terdapat hubungan tiga arah yang mengunci perilaku atau perilaku satu sama lain, lingkungan, dan peristiwa dalam yang memengaruhi persepsi dan tindakan.

Pengaruh Sosialisasi Keuangan terhadap Perilaku Keuangan. Hasil kalkulasi data diaplikasi SmartPLS menunjukan bahwa H4 tidak ditolak (diterima), sehingga variabel sikap keuangan (financial attitude) merupakan prediktor yang positif atas variabel literasi keuangan (financial literacy). Sehingga semakin banyak sosialisasi keuangan yang diterima karyawan muda akan mempengaruhi perilaku keuangan karyawan muda. Sebaliknya dengan semakin sedikit dan buruk sosialisasi keuangan akan menciptakan perilaku keuangan yang buruk dikalangan karyawan muda di kota Jakarta.

Pengaruh Literasi Keuangan terhadap Perilaku Keuangan. Hasil pengujian hipotesis ini sesuai dengan temuan pada penelitian Kumar (2013) menunjukkan bahwa literasi keuangan secara signifikan mempengaruhi perilaku keuangan yang berarti bahwa literasi keuangan berhubungan positif dengan perilaku finansial yang menguntungkan diri sendiri. Ketika orang dewasa muda benar-benar melek finansial, itu akan secara otomatis mempengaruhi perilaku keuangan mereka. Selanjutnya, itu akan mencerminkan keputusan keuangan mereka.

Pengaruh Sikap Keuangan terhadap Perilaku Keuangan melalui variabel mediasi Literasi Keuangan. Besarnya pengaruh tidak langsung ini lebih rendah dari pengaruh langsung tetapi signifikan. Kurangnya pengaruh ini menunjukkan kinerja mediasi literasi keuangan menengah sebagai variabel mediasi, yang berarti bahwa literasi keuangan tidak dapat memediasi pengaruh sempurna antara sikap keuangan terhadap perilaku keuangan karyawan muda. 
Pengaruh Sosialisasi Keuangan terhadap Perilaku Keuangan melalui variabel mediasi Literasi Keuangan. Sosialisasi keuangan dalam penelitian ini memiliki pengaruh terhadap literasi keuangan dan lebih jauh lagi memengaruhi perilaku manajemen keuangan. Jika seseorang lebih banyak berinteraksi dan berinteraksi dengan agen diseminasi keuangan maka semakin tinggi tingkat literasi keuangan yang dimiliki dan kemudian memengaruhi perilaku manajemen keuangan. Ini sesuai dengan penelitian yang dilakukan oleh Sundarasen, et al. (2016).

\section{PENUTUP}

Penelitian ini mencoba mengeksplorasi hubungan antara sikap keuangan, sosialisasi keuangan, literasi keuangan dan perilaku keuangan dikalangan karyawan muda yang bekerja di kota Jakarta. Berdasarkan hasil analisis data dapat disimpulkan bahwa semakin baik sikap keuangan karyawan muda, akan semakin baik juga literasi keuangannya. Semakin banyak sosialisasi keuangan yang diperoleh, semakin baik literasi keuangan karyawan muda. Sebaliknya, semakin sedikit sosialisasi keuangan maka tingkat literasi keuangan yang dimiliki juga akan semakin rendah. Melalui penerapan sikap keuangan dan sosialisasi keuangan yang baik dalam manajemen keuangan, akan mencegah seseorang mengalami personal financial distress.

\section{DAFTAR PUSTAKA}

Ameliawati, M., \& Setiyani, R. (2018). The influence of financial attitude, financial socialization, and financial experience to financial management behavior with financial literacy as the mediation variable. KnE Social Sciences, 811-832.

Arifin, A. Z., Kevin, K., \& Siswanto, H. P. (2017). The Influence of Financial Knowledge, Financial Confidence, and Income on Financial Behavior Among the Workforce in Jakarta. MIX: Jurnal Ilmiah Manajemen, 7(1).

Fluellen, V. M. (2013). Exploring the relationship between financial behaviors and financial well-being of African American college students at one historically black institution.

Lusardi, A., \& Mitchell, O. S. (2014). The economic importance of financial literacy: Theory and evidence. Journal of economic literature, 52(1), 5-44.

Mien, N. T. N., \& Thao, T. P. (2015). Factors affecting personal financial management behaviors: evidence from vietnam. In Proceedings of the Second Asia-Pacific Conference on Global Business, Economics, Finance and Social Sciences (AP15Vietnam Conference), 10-12/07/2015.

Sundarasen, S. D. D., Rahman, M. S., Othman, N. S., \& Danaraj, J. (2016). Impact of financial literacy, financial socialization agents, and parental norms on money management. Journal of Business Studies Quarterly, 8(1), 137.

Yushita, A. N. (2017). Pentingnya literasi keuangan bagi pengelolaan keuangan pribadi. Nominal, Barometer Riset Akuntansi dan Manajemen, 6(1).

Wan, R. (2017, Oktober 13). kompasiana: $\mathrm{h}$ ttps://www.kompasiana.com/ronaldwan/59e04372147f967f532a23f2/nudge-theorybuah-pemikiran-pemenang-nobel-ekonomi-2017?page $=$ all 